\title{
Effects of Particle Size of Alfalfa-Based Dairy Cow Diets on Chewing Activity, Ruminal Fermentation, and Milk Production ${ }^{1}$
}

\author{
K. A. Beauchemin, W. Z. Yang, and L. M. Rode ${ }^{2}$ \\ Livestock Sciences Section, Research Centre \\ Agriculture and Agri-Food Canada, \\ Lethbridge, AB, T1J 4B1, Canada
}

\section{ABSTRACT}

Effects of forage particle size measured as physically effective NDF and ratio of alfalfa silage to alfalfa hay of diets on feed intake, chewing activity, particle size reduction, salivary secretion, ruminal fermentation, and milk production of dairy cows were evaluated using a $4 \times 4$ Latin square design with a $2 \times 2$ factorial arrangement of treatments. The diets consisted of $60 \%$ barley-based concentrate and $40 \%$ forage, comprised either of 50:50 or 25:75 of alfalfa silage:alfalfa hay, and alfalfa hay was either chopped or ground. Various methods were used to determine physically effective NDF content of the diets. Cows surgically fitted with ruminal and duodenal cannulas were offered ad libitum access to these total mixed diets. The physically effective NDF content of the diets was significantly lower when measured using the Penn State Particle Separator than when measured based on particles retained on 1.18-mm screen. Intake of DM was increased by increasing the ratio of silage to hay but was not affected by physically effective NDF content of diets. Eating time (hours per day) was not affected by the physically effective NDF content of diets, although cows spent more time eating per unit of DM or NDF when consuming high versus low alfalfa hay diets. Ruminating time (hours per day) was increased with increased physically effective NDF content of the diets. Rumen $\mathrm{pH}$ was affected more by changing dietary particle size than altering the ratio of silage to hay. Feeding chopped hay instead of ground hay improved ruminal $\mathrm{pH}$ status: time during which ruminal $\mathrm{pH}$ was above 6.2 increased and time during which ruminal $\mathrm{pH}$ was below 5.8 decreased. Milk production was increased by feeding higher concentrations of alfalfa silage due to increased DM intake, but was not

\footnotetext{
Received September 26, 2001.

Accepted July 10, 2002.

Corresponding author: K. A. Beauchemin; e-mail: beauchemin@ agr.gc.ca.

${ }^{1}$ Contribution number: 38701057.

${ }^{2}$ Current address: Rosebud Technologies Development, Ltd., 3302 Beauvais Pl. S., Lethbridge, AB, T1K 3J5, Canada.
}

affected by dietary particle size. Feed particle size, expressed as mean particle length or physically effective NDF was moderately correlated with ruminating time but not with eating time. Although physically effective NDF and chewing time were not correlated to mean rumen $\mathrm{pH}$, they were negatively correlated to the area between the curve and $\mathrm{pH} 5.8$, indicating a positive effect on reducing the risk of acidosis. Milk fat content was correlated to rumen $\mathrm{pH}$ but not to physically effective NDF or chewing activity. These results indicate that increasing physically effective NDF content of the diets increased chewing activity and improved rumen $\mathrm{pH}$ status but had limited effect on milk production and milk fat content.

(Key words: physically effective NDF, chewing behavior, rumen $\mathrm{pH}$, dairy cow)

Abbreviation key: $\mathbf{A H}=$ alfalfa hay, $\mathbf{A S}=$ alfalfa silage, AS:AH = ratio of alfalfa silage to alfalfa hay, FPS = forage particle size, $\mathbf{M P L}=$ mean particle length, $\mathbf{p e}=$ physically effective, pef $=$ physical effectiveness factor, $\mathbf{p e f}_{\mathbf{M}}=$ physical effectiveness factor from tabular values of chewing time, pef $_{\mathbf{P}>\mathbf{1 . 1 8}}=$ physical effectiveness factor determined as a percent of DM remaining on a $1.18-\mathrm{mm}$ screen, pef $_{\mathbf{P S}}=$ physical effectiveness factor calculated as the sum of the DM proportions retained on the two sieves of the Penn State Particle Separator, peNDF = physically effective NDF, $\mathbf{p e N D F}_{\mathbf{M}}=$ physically effective NDF measured as the NDF content of the TMR multiplied by pef $_{\mathbf{M}}$, peNDF $_{\mathbf{P}>\mathbf{1 . 1 8}}=$ physically effective NDF measured as the NDF content of the TMR multiplied by pef $_{\mathbf{P}>\mathbf{1 . 1 8}}$, $\mathbf{p e N D F}_{\mathbf{P S}}=$ physically effective NDF measured as the NDF content of the TMR multiplied by pef $_{\text {PS }}$, PSPS $=$ Penn State Particle Separator.

\section{INTRODUCTION}

To meet the energy requirements of high producing lactating dairy cows, diets typically contain relatively high proportions of concentrate and high quality forages. The trend is to feed diets that are relatively low in fiber. While this practice encourages maximal milk production, it can also lead to one or more of a variety 
of metabolic disorders, including subclinical ruminal acidosis, reduced fiber digestion, milk fat depression, displaced abomasum, laminitis, and fat-cow syndrome (NRC, 2001). Therefore, adequate particle length of forages is necessary for proper ruminal function as coarse particles stimulate chewing activity and hence increase saliva output.

Alfalfa forage, conserved as silage (AS) or hay (AH), is a major component of diets fed to lactating dairy cows. Alfalfa has become a popular forage for silage because of its high DM yield and CP content. Cows can consume large quantities of alfalfa and produce more milk (Nelson and Satter, 1990) when silage is fed as the sole source of forage because NDF is relatively low and is digested rapidly. However, AS is smaller in particle size than long $\mathrm{AH}$, is less brittle and more pliable than hay, and is hydrated. These attributes might reduce effective fiber content of AS and consequently reduce chewing activity predisposing cows to ruminal acidosis. Several studies showed that supplementation of AS-based diets with $\mathrm{AH}$ increased milk production as a result of increasing ruminating time, improving rumen function, and therefore enhancing the digestion of nutrients (Santini et al., 1983; Beauchemin and Buchanan-Smith, 1989).

In addition, the concept of physically effective (pe) fiber was recently introduced (Mertens, 1997) to relate the physical characteristics of feeds to rumen $\mathrm{pH}$ by measuring particle length or chewing activity. It was proposed that the physically effective fiber (peNDF) of feeds can be measured as the NDF content of feeds multiplied by the physically effective factor (pef), which can be determined either as the proportion of the feed retained on a 1.18-mm sieve using a dry sieving technique (Mertens, 1997) or as the sum of the DM retained on the two sieves of the Penn State Particle Separator (PSPS; Lammers et al., 1996). However, neither system has been adequately validated and there is very limited information to establish the requirements of peNDF for dairy cows and to determine the peNDF values of feeds.

The objectives of this study were to evaluate the effects of peNDF content of alfalfa-based diets on feed intake, chewing activity, ruminal fermentation pattern, and milk production and composition by dairy cows. The peNDF contents of the diets were determined by multiplying the NDF content of the diets by pef. The pef was measured using various methods including the PSPS, the tabular values from Mertens (2000), or the proportion of DM retained on a 1.18$\mathrm{mm}$ sieve. In addition, particle size of diets differed by altering the ratio of AS to $\mathrm{AH}$ (AS:AH) and using $\mathrm{AH}$ that was either chopped or ground.

\section{MATERIALS AND METHODS}

\section{Forages}

Alfalfa was harvested during the second cutting in a midflowering stage and then preserved as silage in large silo bags (200-tonne capacity). A forage harvester (model 5830; John Deere, West Bend, WI), equipped with a 37 -tooth sprocket and 8 knives, was used to obtain silage chopped at a theoretical length of $10 \mathrm{~mm}$. Once the silage was preserved and a chemical analysis was determined, a second-cutting $\mathrm{AH}$ of similar quality was purchased for the study. The AH was preserved in small rectangular bales. The AH was coarsely chopped by using a bale processor without screen attachment (Agri-Metal bale processor) driven by a $90 \mathrm{Hp}$ tractor. The amount required for the whole experiment was prepared and stored indoors in the feed processing facility. The ground $\mathrm{AH}$ was prepared as needed by grinding the chopped $\mathrm{AH}$ through a 4mm screen.

Forages (AS, chopped or ground $\mathrm{AH}$ ) were sampled once a week with approximately $1 \mathrm{~kg}$ of each forage obtained. Before sampling, the piles of chopped and ground hay were turned manually using a pitch fork to minimize layering and possible separation of small particles. The DM content was determined by ovendrying at $55^{\circ} \mathrm{C}$ for $48 \mathrm{~h}$. The samples were then composited by each experimental period. Chemical composition and particle size distributions of the forages were determined on each composited sample.

\section{Cows and Diets}

Four lactating Holstein cows that were surgically fitted with ruminal and duodenal cannulas were used. The ruminal cannulas measured $10 \mathrm{~cm}$ in diameter and were constructed of soft plastic (Bar Diamond, Parma, ID). The duodenal cannulas were T-type and placed proximal to the bile and pancreatic ducts approximately $10-\mathrm{cm}$ distal to the pylorus. At the start of the experiment, the cows averaged $655 \pm 79 \mathrm{~kg}$ of BW and $127 \pm 38$ DIM and were housed in individual tie stalls and milked twice daily in their stalls at 0700 and $1700 \mathrm{~h}$. Cows were offered a TMR three times daily at 0800,1500 , and $1800 \mathrm{~h}$ for ad libitum intake. Cows were weighed at approximately $1030 \mathrm{~h}$ at the beginning and end of each period and these weights were used to calculate mean BW of cows for each experimental period. Cows were cared for according to the Canadian Council on Animal Care Guidelines (Ottawa, ON).

The experimental design was a $4 \times 4$ Latin square with four 21-d periods and a $2 \times 2$ factorial arrangement of treatments: AS:AH (high vs. low, 50:50 vs. 
Table 1. Ingredients and chemical composition of the total mixed diet (DM basis).

\begin{tabular}{|c|c|c|}
\hline \multirow[b]{2}{*}{ Item } & \multicolumn{2}{|c|}{ Diets (alfalfa silage:alfalfa hay) } \\
\hline & $50: 50$ & $25: 75$ \\
\hline \multicolumn{3}{|l|}{ Ingredients, \% } \\
\hline Alfalfa silage ${ }^{1}$ & 19.7 & 10.2 \\
\hline Alfalfa hay ${ }^{1}$ & 19.7 & 29.5 \\
\hline Steam-rolled barley grain ${ }^{1}$ & 46.1 & 45.5 \\
\hline Corn gluten meal & 3.01 & 1.94 \\
\hline Heat-treated canola meal (Alberta Gold) & 1.70 & 2.66 \\
\hline Soybean meal & 4.51 & 4.36 \\
\hline Beet molasses & 0.97 & 0.97 \\
\hline Urea & - & 0.29 \\
\hline Calcium carbonate & 0.78 & 0.77 \\
\hline Dicalcium phosphate & 0.39 & 0.39 \\
\hline Monophosphate & 0.29 & 0.29 \\
\hline Vitamin and mineral premix ${ }^{2}$ & 1.94 & 1.94 \\
\hline Canola oil & 0.82 & 0.97 \\
\hline Binding agent (Aka) & 0.19 & 0.19 \\
\hline \multicolumn{3}{|l|}{ Chemical, $\%$ of DM } \\
\hline $\mathrm{DM}$ & 68.3 & 77.6 \\
\hline $\mathrm{OM}$ & 91.4 & 91.3 \\
\hline $\mathrm{CP}$ & 18.0 & 18.5 \\
\hline $\mathrm{NDF}$ & 36.1 & 36.0 \\
\hline NDF from forages & 19.5 & 18.6 \\
\hline Starch & 29.5 & 28.7 \\
\hline $\mathrm{NE}_{\mathrm{L}}, \mathrm{Mcal} / \mathrm{kg}^{3}$ & 1.58 & 1.59 \\
\hline
\end{tabular}

${ }^{1}$ Chemical composition of alfalfa silage, alfalfa hay, and barley grain (DM basis) was 89.8, 90.8, and $97.7 \%$ for $\mathrm{OM} ; 55.2,52.3$, and $25.2 \%$ for NDF; $48.0,42.5$, and $6.7 \%$ for $\mathrm{ADF} ; 16.6,17.7$, and $13.9 \%$ for $\mathrm{CP}$, respectively.

${ }^{2}$ Contained $51.97 \% \mathrm{NaCl}, 35.98 \%$ Dynamate7 (Pitman Moore, Inc., Mundelein, IL; $18 \% \mathrm{~K}, 11 \% \mathrm{Mg}$, $22 \% \mathrm{~S}, 1000 \mathrm{mg} \mathrm{Fe} / \mathrm{kg}$ ), $2 \% \mathrm{ZnSO}_{4} \cdot \mathrm{H}_{2} \mathrm{O}, 2.4 \% \mathrm{MnSO}_{4} \cdot 4 \mathrm{H}_{2} \mathrm{O}, 0.01 \% \mathrm{CoSO}_{4} \cdot 6 \mathrm{H}_{2} \mathrm{O}, 0.009 \% \mathrm{Na}_{2} \mathrm{SeO}_{3}, 0.012 \%$ ethylenediamine dihydroiodide, $0.8 \% \mathrm{CuSO}_{4} \cdot 5 \mathrm{H}_{2} \mathrm{O}, 680,000 \mathrm{IU} / \mathrm{kg}$ of vitamin $\mathrm{A}, 160,000 \mathrm{IU} / \mathrm{kg}$ of vitamin $\mathrm{D}$ and $2,000 \mathrm{IU} / \mathrm{kg}$ of vitamin E.

${ }^{3}$ Estimated from NRC (1989).

25:75) combined with particle size of the hay (FPS). The diets were formulated using the Cornell-PennMiner System (CPMDairy, Version 1.0) to supply adequate metabolizable energy and protein for a $650-\mathrm{kg}$ cow producing $30 \mathrm{~kg} / \mathrm{d}$ of milk with $3.5 \%$ fat and $3.2 \%$ protein (Table 1). The diets consisted of $60 \%$ barleybased concentrate and $40 \%$ forage. Differences in mean particle length and the pef of the diets were created by manipulating the AS:AH and particle size of the AH (Tables 2 and 3).

Barley grain obtained from one source was used throughout the experiment. The barley was first screened to remove chaff and small kernels and then steam-rolled to an optimum degree of rolling for dairy cows as described by Yang et al. (2000), which was a processing index of 65\%. Processing index was defined as the ratio of the volume weight of the barley after processing to its volume weight before processing.

Each period consisted of 11-d of adaptation to diets and 10-d of experimental measurements consisting of chewing activity, salivary secretion during eating, particle size distribution of feed and ingesta, ruminal fermentation characteristics, feed intake, and milk production and composition.

\section{Chewing Activities, Salivary Secretion, and Particle Size Distribution}

Chewing activities of the four cows were monitored visually every 5 min for a 24 -h period from the 13 th to 14 th day of the experimental period. The assumption was made that the particular chewing activity persisted for the entire 5-min period between each visual observation. Chewing activities were expressed as total hours for the 24-h period or on the basis of DMI and NDF intake by dividing minutes of eating or ruminating by intake.

Saliva secretion was measured by collecting boluses from the cardia as the cow was eating during the 3 $\mathrm{pm}$ feeding on the 17th day of the period. To facilitate sampling, the rumen was partially emptied to expose the cardia. The entire swallowed material, including boluses and saliva, were collected using a plastic bag mounted on a wire hoop inserted through the rumen cannula. Five sequential collections were made by collecting for 2 min at 3-min intervals. Each sample of masticate was weighed and divided into two subsamples: one was dried in an oven at $55^{\circ} \mathrm{C}$ for $48 \mathrm{~h}$ to determine DM content, and the other was pooled by 
Table 2. Distribution of particles, particle length, and physical effectiveness factors of forages.

\begin{tabular}{|c|c|c|c|c|}
\hline \multirow[b]{2}{*}{ Item } & \multirow[b]{2}{*}{ Alfalfa silage } & \multicolumn{2}{|c|}{ Alfalfa hay } & \multirow[b]{2}{*}{$\mathrm{SE}$} \\
\hline & & Chopped & Ground & \\
\hline \multicolumn{5}{|c|}{ Penn State Particle Separator } \\
\hline \multicolumn{5}{|c|}{ DM retention on sieve, $\%$} \\
\hline Top, 19-mm & $4.7^{\mathrm{b}}$ & $24.8^{\mathrm{a}}$ & $0.0^{\mathrm{c}}$ & 1.8 \\
\hline Middle, 8-mm & $68.7^{\mathrm{a}}$ & $24.7^{\mathrm{b}}$ & $0.6^{\mathrm{c}}$ & 1.4 \\
\hline Bottom & $26.7^{\mathrm{c}}$ & $50.5^{b}$ & $99.4^{\mathrm{a}}$ & 2.8 \\
\hline $\operatorname{pef}_{\mathrm{PS}}{ }^{1}, \%$ & $73.4^{\mathrm{a}}$ & $49.5^{\mathrm{b}}$ & $0.6^{\mathrm{c}}$ & 2.70 \\
\hline $\operatorname{pef}_{\mathrm{M}}^{2}, \%$ & 85 & 80 & 40 & - \\
\hline $\operatorname{pef}_{\mathrm{P}>1.18^{3}, \%}$ & $66.0^{\mathrm{a}}$ & $53.5^{\mathrm{b}}$ & $36.0^{\mathrm{c}}$ & 0.8 \\
\hline \multicolumn{5}{|l|}{ Wet sieving } \\
\hline \multicolumn{5}{|c|}{ DM retained on sieve, $\%$} \\
\hline 9.50 & $19.7^{\mathrm{a}}$ & $18.6^{\mathrm{a}}$ & $0.0^{\mathrm{b}}$ & 0.7 \\
\hline 6.70 & $10.6^{\mathrm{a}}$ & $6.2^{\mathrm{b}}$ & $0.0^{\mathrm{c}}$ & 0.1 \\
\hline 3.35 & $20.5^{\mathrm{a}}$ & $14.9^{\mathrm{b}}$ & $2.8^{\mathrm{c}}$ & 0.3 \\
\hline 1.18 & $13.0^{\mathrm{b}}$ & $9.9^{\mathrm{b}}$ & $28.3^{\mathrm{a}}$ & 0.8 \\
\hline 0.60 & $3.4^{\mathrm{c}}$ & $7.6^{\mathrm{b}}$ & $11.7^{\mathrm{a}}$ & 0.4 \\
\hline 0.15 & $7.7^{\mathrm{b}}$ & $15.1^{\mathrm{ab}}$ & $20.9^{\mathrm{a}}$ & 3.5 \\
\hline Not retained & $25.1^{\mathrm{b}}$ & $27.8^{\mathrm{ab}}$ & $36.4^{\mathrm{a}}$ & 3.5 \\
\hline $\mathrm{MPL}^{4}, \mathrm{~mm}$ & $7.93^{\mathrm{a}}$ & $5.67^{\mathrm{b}}$ & $2.22^{\mathrm{c}}$ & 0.13 \\
\hline
\end{tabular}

${ }^{\mathrm{a}, \mathrm{b}, \mathrm{c}}$ Means within the same row not followed by the same letter differ $(P<0.05)$.

${ }^{1}$ Physical effectiveness factor determined as the proportion of dry matter retained by both sieves of the Penn State Particle Separator.

${ }^{2}$ Physical effectiveness factor based on chewing activity determined by Mertens (1997).

${ }^{3}$ Physical effectiveness factor determined as a percent of DM remaining on a $1.18-\mathrm{mm}$ screen measured using a wet sieving technique.

${ }^{4}$ Fifty percent of the particles are greater or less than this length.

cow and stored frozen at $-20^{\circ} \mathrm{C}$ for particle size analysis. Saliva output was estimated as the additional moisture content of the boluses relative to the moisture content of the diet which was sampled at the same time as the bolus collection. Salivation rate (milliliter per minute) was calculated for each individual collec- tion as the ratio between the total amount of saliva obtained and the duration of that collection. Ensalivation (milliliter per gram of DMI) of the feed was calculated as the amount of saliva added per gram of feed ingested. The daily saliva production during eating was estimated either by multiplying the eating saliva-

Table 3. Particle size distribution and physical effectiveness factors of diets.

\begin{tabular}{|c|c|c|c|c|c|c|c|c|}
\hline \multirow[b]{3}{*}{ Item } & \multicolumn{4}{|c|}{$\operatorname{Diets}^{1}$} & \multirow[b]{3}{*}{ SE } & \multicolumn{3}{|c|}{ Effect $^{2}, P<$} \\
\hline & \multicolumn{2}{|c|}{ AS:AH 50:50 } & \multicolumn{2}{|c|}{ AS:AH 25:75 } & & \multirow[b]{2}{*}{ AS:AH } & \multirow[b]{2}{*}{ FPS } & \multirow{2}{*}{$\begin{array}{l}\text { AS:AH } \\
\times \text { FPS }\end{array}$} \\
\hline & $\overline{\mathrm{CH}}$ & $\mathrm{GH}$ & $\overline{\mathrm{CH}}$ & $\mathrm{GH}$ & & & & \\
\hline \multicolumn{9}{|c|}{ Feed retention on sieve, $\%$} \\
\hline Top, $19-\mathrm{mm}$ & 9.4 & 0.8 & 11.9 & 0.2 & 1.1 & $\mathrm{~ns}$ & 0.01 & $\mathrm{~ns}$ \\
\hline Middle, 8-mm & 32.1 & 29.9 & 25.8 & 21.6 & 1.7 & 0.01 & 0.10 & $\mathrm{~ns}$ \\
\hline Bottom & 58.6 & 69.3 & 62.3 & 78.2 & 2.2 & 0.02 & 0.01 & $\mathrm{~ns}$ \\
\hline $\operatorname{pef}_{\mathrm{PS}}{ }^{3}, \%$ & 41.3 & 30.7 & 37.7 & 21.9 & 2.1 & 0.02 & 0.01 & $\mathrm{~ns}$ \\
\hline $\operatorname{pef}_{\mathrm{M}}^{4}, \%$ & 67.5 & 59.7 & 66.8 & 55.0 & - & - & - & - \\
\hline $\operatorname{pef}_{\mathrm{P}>1.18^{5}, \%}$ & 73.5 & 63.6 & 68.8 & 59.4 & 1.2 & 0.02 & 0.01 & $\mathrm{~ns}$ \\
\hline
\end{tabular}

${ }^{1} \mathrm{AS}: \mathrm{AH}$ = Ratio of alfalfa silage to alfalfa hay; $\mathrm{CH}$ = chopped hay; $\mathrm{GH}$ = ground hay; and the overall diet was $60 \%$ barley-based concentrate and $40 \%$ forage on a DM basis.

${ }^{2} \mathrm{FPS}=$ forage particle size.

${ }^{3}$ Physical effectiveness factor determined as the proportion of dry matter retained by both sieves of the Penn State Particle Separator.

${ }^{4}$ Physical effectiveness factor based on chewing determined from Mertens (1997). The pef of steam-rolled barley was assumed to be $70 \%$.

${ }^{5}$ Physical effectiveness factor determined as a percent of DM remaining on a 1.18-mm screen measured using a wet sieving technique.

$\mathrm{ns}=P>0.15$. 
tion rate (milliliter per minute) by the time spent eating each day (minute) or by multiplying the ensalivation of the feed (milliliter per gram of DMI) by DMI.

Samples of ruminal contents and duodenal digesta were also obtained for particle size determination. $\mathrm{Ru}$ minal samples were collected by total evacuation of rumen contents, which were manually emptied at 9:30 a.m. on the last day of the period. Duodenal samples were collected during the last 3-d of the period. Samples were taken four times daily every $6 \mathrm{~h}$ moving ahead $2 \mathrm{~h}$ each day. The duodenal samples were then pooled by cow for each period.

\section{Ruminal Fermentation}

Rumen $\mathrm{pH}$ was measured by placing an industrial electrode (model PHCN-37; Omega Engineering, Stanford, CT) through the rumen cannulae into the ventral sac of the rumen within each cow for a 48-h period. A weight was attached to the electrode to ensure it remained in the ventral sac. A protective shield with large openings that allowed rumen fluid to percolate freely was placed around the electrode to prevent it from coming in direct contact with the ruminal epithelium. The electrodes were calibrated with $\mathrm{pH} 4.0$ and 7.0 standards at 0,24 and $48 \mathrm{~h}$ of the measurement period. The $\mathrm{pH}$ was measured every five seconds, averaged every $15 \mathrm{~min}$, and recorded using a data logger. Mean ruminal $\mathrm{pH}$ for each cow in each period was determined by averaging the data collected during the $48 \mathrm{~h}$. Hours during which $\mathrm{pH}$ was above 6.2 or below 5.8 were calculated assuming that the change of $\mathrm{pH}$ between two measuring times was linear. The area below $\mathrm{pH} 5.8$ (or 6.2) and the $\mathrm{pH}$ curve was calculated for each cow over the entire $\mathrm{pH}$ measurement period. The area was calculated by adding the absolute value of the negative deviations in $\mathrm{pH}$ from 5.8 (or 6.2) for each 15-min interval. Values were expressed as $\mathrm{pH}$ units multiplied by hours. The ruminal $\mathrm{pH} 6.2$ and 5.8 were chosen as benchmarks based on in vitro observations that ruminal microbial activity is compromised when ruminal $\mathrm{pH}$ drops below 6.2 (Russell and Wilson, 1996), and the incidence of sub-clinical acidosis increases when ruminal $\mathrm{pH}$ falls below 5.8. The lowest $\mathrm{pH}$ for each cow over the entire period was also recorded.

Ruminal fluid was collected on $1 \mathrm{~d}$ at 1000, 1300, and $1600 \mathrm{~h}$ from multiple sites in the rumen. Samples were immediately squeezed through four layers of cheesecloth with a mesh size of $250 \mu \mathrm{m}$. Five milliliters of filtrate were preserved by adding $1 \mathrm{ml}$ of $25 \% \mathrm{HPO}_{3}$ to determine VFA, and $9 \mathrm{ml}$ of filtrate were preserved by adding $1 \mathrm{ml}$ of $1 \% \mathrm{H}_{2} \mathrm{SO}_{4}$ to determine $\mathrm{NH}_{3} \mathrm{~N}$.
The samples were subsequently stored frozen at $-20^{\circ} \mathrm{C}$ until analyzed.

\section{Feed Intake and Milk Production}

Feed offered and orts were measured and recorded daily during the last 10 -d of the period to calculate feed intake. Feed samples were collected once weekly, and orts were collected twice weekly for DM determination. Samples were ground through a $1-\mathrm{mm}$ diameter screen (standard model 4; Arthur Thomas Co., Philadelphia, PA) and composited by period for analysis of OM, NDF, ADF, starch, and CP. Milk production was recorded daily, am and pm, and sampled on five consecutive days during the last 10-d of the period. Milk samples were preserved with potassium dichromate, stored at $4^{\circ} \mathrm{C}$, and sent to the Central Alberta Milk Testing Laboratory (Edmonton, AB, Canada) for milk fat, $\mathrm{CP}$, and lactose determination by using an infrared analyzer (Milk-O-Scan 605; Foss Electric, Hillerød, Denmark).

Feed DM was determined by oven-drying at $55^{\circ} \mathrm{C}$ for $48 \mathrm{~h}$. Analytical DM content of the samples was determined by drying at $135^{\circ} \mathrm{C}$ for $3 \mathrm{~h}$ (AOAC, 1990). The OM content was calculated as the difference between DM and ash contents, with ash determined by combustion at $550^{\circ} \mathrm{C}$ overnight. Content of $\mathrm{CP}$ in the samples was determined by flash combustion (Carlo Erba Instruments, Milan, Italy). The NDF and ADF contents were determined using the methods described by Van Soest et al. (1991) with amylase and sodium sulfite used in the NDF procedure. Starch was determined by enzymatic hydrolysis of $\alpha$-linked glucose polymers as described previously (Rode et al., 1999). Ruminal VFA were separated and quantified by gas chromatography (Varian 3700; Varian Specialties Ltd., Brockville, ON) using a 15-m (0.53-mm i.d.) fused silica column (DB-FFAP column; J and W Scientific, Folsom, CA). Ammonia content of ruminal samples was determined using the method described by Weatherburn (1967) modified to use a plate reader.

Particle size distributions of the forages and TMR were measured using the PSPS or by wet sieving (Tables 2 and 3). The pef of forages and TMR were obtained in different ways: pef $\mathbf{P S}_{\mathbf{P S}}$ was calculated as the sum of the proportions retained on the two sieves of the PSPS, and pef $_{\mathbf{M}}$ was calculated based on tabular values from Mertens (2000). The pef $_{\mathbf{P}>\mathbf{1 . 1 8}}$ was determined as a percent of DM remaining on a $1.18 \mathrm{~mm}$ screen (diameter i.d. $20.5 \mathrm{~cm}$; W. S. Tyler Inc., Mentor, $\mathrm{OH})$. The peNDF was calculated by multiplying NDF content of the TMR by pef determined in each manner.

Particle size distributions of forages, TMR and digestive contents were measured by wet sieving using a 
vertical oscillating sieve shaker (Analysette 3; Fritsch, Oberstein, Germany) equipped with a stack of sieves (diameter i.d. $20.5 \mathrm{~cm}$; W. S. Tyler Inc.) arranged in descending pore size. Sieve pore sizes were 9.5, 6.7, $3.35,1.18,0.6$, and $0.15 \mathrm{~mm}$ for forages, diets, and rumen contents, and $3.35,1.18,0.6$, and $0.15 \mathrm{~mm}$ for duodenal contents. Approximately $15 \mathrm{~g}$ of feed or 30 $\mathrm{g}$ of wet digesta were placed on the top screen, and the stack of sieves were shaken until the distribution of material did not change (approximately $10 \mathrm{~min}$ ). Based on the overbalancing principle described by Vaage et al. (1984), it was assumed that the minimum particle length of material retained on each sieve was equal to twice the diagonal dimension of the sieve aperture. The cumulative percentage of sample weight that was below this minimum size was calculated for each sieve size as detailed by Lammers et al. (1996).

Because a wet sieving technique was used, it was necessary to account for the loss of DM due to solubilization prior to calculating mean particle length (MPL). The MPL of feeds reported are comparable to values determined by a dry sieving technique. This adjustment was made by using nonlinear optimization to fit the following modified Weibull function to the data for each sieve:

$$
\mathrm{y}=100\left(1-\mathrm{e}^{-\mathrm{b}\left(\mathrm{x}-\mathrm{x}_{0}\right) \mathrm{c}}\right)
$$

where

$$
\begin{aligned}
\mathrm{y}= & \text { cumulative percentage of sample weight } \\
& \text { retained by each sieve } \\
\mathrm{b}, \mathrm{c}= & \text { parameters of the Weibull function, } \\
\mathrm{X}= & \text { total DM passing through the each sieve } \\
& \text { including small particles and solubles, } \\
& \text { and } \\
\mathrm{X}_{0}= & \text { the Y-intercept. }
\end{aligned}
$$

The value of $\mathrm{X}_{0}$ represented the true soluble fraction, and it was assumed based on unpublished studies in our laboratory that the solubles were extracted from each particle size fraction in proportion to the surface area of the smallest particles in that fraction. Surface area of particles was calculated assuming particle length was 5-times particle width, width of particles was 5-times particle thickness, and all particles had a density of $1 \mathrm{mg} / \mathrm{mm}^{3}$. The DM retained on each sieve was adjusted by adding the calculated proportion of soluble DM to this weight. Then a second Weibull function was fitted to the adjusted cumulative DM retained on each sieve $\left(\mathrm{X}_{0}=0\right)$ and the parameters were estimated using NLIN procedure of SAS (SAS, 1996). The MPL was calculated as the particle length for which $50 \%$ of the cumulative percentage weight of the sample was retained (Vaage and Shelford, 1984). The percentage of adjusted DM retained on the 1.18-mm screen was the value used for $\mathrm{pef}_{\mathrm{P}>1.18}$ and thus, this estimate was similar to values obtained using a dry sieving technique as recommended by Mertens (1997).

\section{Statistical Analyses}

For each period, means for individual cows were calculated for all variables. Data were analyzed using the mixed model procedure of SAS (Proc Mixed; SAS, 1996). The model included cows, period, AS:AH, FPS, and the two-way interaction between AS:AH and FPS. Period and cow were considered random effects. For ruminal $\mathrm{pH}$ variables, the model also included day and the two-way interactions between treatment and day and a repeated statement was used. The Pearson correlation coefficients were estimated using the CORR procedure of SAS (SAS, 1996). Effects were declared significant at $P<0.05$ unless otherwise noted and trends were discussed at $P<0.15$.

\section{RESULTS AND DISCUSSION}

\section{Particle Size Distributions of Forages and TMR}

The AS used in this study with a pef $\mathrm{PS}_{\mathrm{PS}}=73.4$ was considered medium to coarsely chopped compared to the industry standard. Yet, proportion of particles retained on the top sieve of the PSPS was significantly lower, and proportion of particles retained on the second sieve was threefold higher, for AS than for chopped $\mathrm{AH}$ (Table 2). Few particles were retained on the sieves of the PSPS for ground AH. Consequently, pef $f_{\text {PS }}$ measured as the sum of particles retained on both sieves of the PSPS was highest for the AS, lowest for the ground $\mathrm{AH}$ and intermediate for the chopped $\mathrm{AH}$. $\mathrm{Al}-$ falfa silage and chopped $\mathrm{AH}$ had a similar proportion of particles retained on the 9.5 - or $1.18-\mathrm{mm}$ screens using a wet sieving technique, but a greater proportion of the forage was retained on the $6.7-$ and $3.35-\mathrm{mm}$ screens for the AS than for the chopped AH. Grinding through a 4-mm screen removed most of the coarse particles but gave a higher proportion of particles retained on the 1.18-mm screen or smaller screens compared to the chopped AH. As a result, the MPL and pef $_{\mathrm{P}>1.18}$ of the forages followed the same trend as that of the pef $f_{\mathrm{PS}}$. However, pef was variable among the methods used. The method of Mertens (1997) gave consistently higher pef values than did the other two methods, especially for chopped AH. The pef estimated using the PSPS or the particles retained on the 1.18mm screen was similar for AS and chopped AH but was different for ground $\mathrm{AH}$. 
Table 4. Intake of DM and effective fiber of dairy cows fed diets differing in ratio of alfalfa silage to alfalfa hay or forage particle size.

\begin{tabular}{|c|c|c|c|c|c|c|c|c|}
\hline \multirow[b]{3}{*}{ Item } & \multicolumn{4}{|c|}{$\operatorname{Diets}^{1}$} & \multirow[b]{3}{*}{$\mathrm{SE}$} & \multicolumn{3}{|c|}{ Effect $^{2}, P<$} \\
\hline & \multicolumn{2}{|c|}{ AS:AH 50:50 } & \multicolumn{2}{|c|}{ AS:AH 25:75 } & & \multirow[b]{2}{*}{ AS:AH } & \multirow[b]{2}{*}{ FPS } & \multirow{2}{*}{$\begin{array}{l}\text { AS:AH } \\
\times \text { FPS }\end{array}$} \\
\hline & $\overline{\mathrm{CH}}$ & GH & $\overline{\mathrm{CH}}$ & $\mathrm{GH}$ & & & & \\
\hline \multicolumn{9}{|l|}{ Intake of DM } \\
\hline $\mathrm{kg} / \mathrm{d}$ & 23.5 & 23.9 & 20.6 & 20.5 & 2.1 & 0.06 & ns & ns \\
\hline$\%$ of $\mathrm{BW}$ & 3.54 & 3.71 & 3.18 & 3.24 & 0.29 & 0.09 & ns & ns \\
\hline \multicolumn{9}{|c|}{$\begin{array}{l}\text { Intake of peNDF } \\
\text { peNDF }\end{array}$} \\
\hline $\mathrm{kg} / \mathrm{d}$ & 3.53 & 2.42 & 2.74 & 1.47 & 0.33 & 0.01 & 0.01 & ns \\
\hline $\begin{array}{l}\% \text { of DMI } \\
\text { peNDF }^{5}\end{array}$ & 15.0 & 10.1 & 13.3 & 7.2 & 0.8 & 0.02 & 0.01 & ns \\
\hline $\mathrm{kg} / \mathrm{d}$ & 5.78 & 4.68 & 4.87 & 3.75 & 0.52 & 0.03 & 0.01 & ns \\
\hline $\begin{array}{c}\% \text { of DMI } \\
\operatorname{peNDF}_{\mathrm{P}>1.18}{ }^{6}\end{array}$ & 24.5 & 19.6 & 23.6 & 18.3 & 0.4 & 0.02 & 0.01 & ns \\
\hline $\mathrm{kg} / \mathrm{d}$ & 6.29 & 4.98 & 4.99 & 4.06 & 0.53 & 0.01 & 0.01 & ns \\
\hline$\%$ of DMI & 26.7 & 20.9 & 24.3 & 19.7 & 0.3 & 0.01 & 0.01 & 0.01 \\
\hline $\mathrm{BW}, \mathrm{kg}$ & 663 & 646 & 648 & 634 & 5.4 & 0.06 & 0.03 & $\mathrm{~ns}$ \\
\hline
\end{tabular}

\footnotetext{
${ }^{1} \mathrm{AS}: \mathrm{AH}=$ Ratio of alfalfa silage to alfalfa hay; $\mathrm{CH}=$ chopped hay; $\mathrm{GH}=$ ground hay; and the overall diet was $60 \%$ barley-based concentrate and $40 \%$ forage on a DM basis.

${ }^{2} \mathrm{FPS}=$ forage particle size.

${ }^{3}$ Physically effective NDF.

${ }^{4}$ Physically effective NDF measured as the NDF intake multiplied by pef $f_{\text {PS }}$ (Table 3 ).

${ }^{5}$ Physically effective NDF measured as the NDF intake multiplied by pef M $_{\mathrm{M}}$ (Table 3 ).

${ }^{6}$ Physically effective NDF measured as the NDF intake multiplied by $\operatorname{pef}_{P}>1.18$ (Table 3 ).

$\mathrm{ns}=P>0.15$.
}

The TMR used in this study containing AS and chopped AH was considered of sufficient particle size to maintain healthy rumen function, whereas the diets containing AS and ground $\mathrm{AH}$ were designed to supply less than adequate particle size. Consequently, for the TMR, the fraction of particles retained on the top screen of the PSPS was not affected by the AS:AH but was reduced by replacing chopped $\mathrm{AH}$ with ground AH (Table 3). However, the fraction of the particles retained on the second screen of the PSPS was more affected by the AS:AH than the FPS because pef $f_{\mathrm{PS}}$ was significantly different for the AS and the AH. The pef of the diets was affected both by the AS:AH and the FPS regardless of the method used to determine FPS. However, the pef $f_{\mathrm{PS}}$ was only about $50 \%$ of the pef $\mathrm{f}_{\mathrm{M}}$ or pef $_{\mathrm{P}>1.18}$ since the pef $f_{\mathrm{PS}}$ did not include steam-rolled barley while the pef $_{\mathrm{M}}$ or pef $_{\mathrm{P}>1.18}$ did. In fact, over $80 \%$ of the rolled barley kernels are retained by a $3.35 \mathrm{~mm}$ screen (Yang et al., 2000).

\section{Intakes of DM and peNDF}

Intake of DM, expressed as kilograms per day or as percentage of BW, did not differ for cows fed diets containing chopped hay or ground hay but tended ( $P$ $<0.10)$ to differ with a change of the ratio of AS:AH (Table 4). Lack of effect of FPS on DMI was consistent with the results of Rode et al. (1985) and Soita et al. (2000) but was opposite to others (Jaster and Murphy, 1983; Rode and Satter, 1988). Influence of FPS on DMI may depend upon forage level in the diets of dairy cows. Belyea et al. (1985) reported that decreased FPS increased intake of cows fed only forage, but FPS had no effect on intake of cows fed forage plus concentrate because ruminal fill was not a limiting factor for DMI. In addition, DMI was affected by long forage but not by chopped or ground forage in diets of dairy cows (Rode et al., 1985). Effect of alfalfa preservation (silage vs. hay) on DMI is inconsistent in the literature. Nelson and Satter (1992) reported that cows fed AS-based diets consumed $1.2 \mathrm{~kg}$ more DM than those fed AHbased diets, while others (Broderick, 1995; Beauchemin et al., 1997) found that DMI was higher for cows fed $\mathrm{AH}$ than for cows fed AS.

Intake of peNDF followed the same trend as pef contents of the diets and was affected by both FPS and AS:AH. Cows fed the diets containing chopped AH or high AS:AH had greater intake of peNDF than did cows fed the diets containing ground $\mathrm{AH}$ or low $\mathrm{AS}: \mathrm{AH}$ because pef was higher for AS than for $\mathrm{AH}$ and peNDF of the diets was estimated based on particle size of the diets. In addition, proportion of peNDF $_{\mathrm{M}}$ and peNDF $\mathrm{P}>$ 1.18 in the diets (DM basis) varied from 18.3 to $26.7 \%$ of DM which was in the range of the minimum recom- 
Table 5. Chewing activity and salivary production during eating of dairy cows fed diets differing in ratio of alfalfa silage to alfalfa hay or forage particle size.

\begin{tabular}{|c|c|c|c|c|c|c|c|c|}
\hline \multirow[b]{3}{*}{ Item } & \multicolumn{4}{|c|}{$\operatorname{Diets}^{1}$} & \multirow[b]{3}{*}{$\mathrm{SE}$} & \multicolumn{3}{|c|}{ Effect $^{2}, P<$} \\
\hline & \multicolumn{2}{|c|}{ AS:AH 50:50 } & \multicolumn{2}{|c|}{ AS:AH 25:75 } & & \multirow[b]{2}{*}{ AS:AH } & \multirow[b]{2}{*}{ FPS } & \multirow{2}{*}{$\begin{array}{l}\text { AS:AH } \\
\times \text { FPS }\end{array}$} \\
\hline & $\mathrm{CH}$ & $\mathrm{GH}$ & $\mathrm{CH}$ & GH & & & & \\
\hline \multicolumn{9}{|l|}{ Chewing activity } \\
\hline \multicolumn{9}{|l|}{ Eating activity } \\
\hline $\mathrm{h} / \mathrm{d}$ & 4.8 & 4.2 & 4.7 & 5.3 & 0.3 & ns & ns & 0.09 \\
\hline $\mathrm{Min} / \mathrm{kg} \mathrm{DM}$ & 12.5 & 10.8 & 14.8 & 15.5 & 1.7 & 0.01 & ns & $\mathrm{ns}$ \\
\hline $\mathrm{Min} / \mathrm{kg} \mathrm{NDF}$ & 34.5 & 32.9 & 42.2 & 46.6 & 5.2 & 0.02 & ns & ns \\
\hline \multicolumn{9}{|l|}{ Ruminating time } \\
\hline $\mathrm{h} / \mathrm{d}$ & 7.3 & 6.2 & 7.0 & 4.6 & 0.6 & 0.04 & 0.01 & 0.08 \\
\hline $\mathrm{Min} / \mathrm{kg} \mathrm{DM}$ & 19.1 & 15.7 & 20.8 & 13.5 & 1.6 & $\mathrm{~ns}$ & 0.01 & 0.07 \\
\hline Min/kg NDF & 52.7 & 48.1 & 59.1 & 40.5 & 5.1 & ns & 0.01 & 0.07 \\
\hline \multicolumn{9}{|l|}{ Total chewing time } \\
\hline $\mathrm{h} / \mathrm{d}$ & 12.1 & 10.4 & 11.7 & 9.9 & 0.8 & ns & 0.02 & $\mathrm{~ns}$ \\
\hline Min/kg DM & 31.6 & 26.5 & 35.6 & 28.9 & 2.7 & 0.07 & 0.01 & $\mathrm{~ns}$ \\
\hline Min/kg NDF & 87.1 & 81.0 & 101.3 & 87.1 & 8.6 & 0.11 & 0.11 & $\mathrm{~ns}$ \\
\hline \multicolumn{9}{|l|}{ Salivary secretion } \\
\hline Salivation rate $^{3}, \mathrm{ml} / \mathrm{min}$ & 198.9 & 191.1 & 173.9 & 219.6 & 15.2 & $\mathrm{~ns}$ & ns & 0.08 \\
\hline Ensalivation $^{4}, \mathrm{ml} / \mathrm{g} \mathrm{DM}$ & 3.7 & 2.6 & 2.7 & 3.7 & 0.3 & ns & ns & 0.05 \\
\hline \multicolumn{9}{|l|}{ Output during eating, L/d } \\
\hline Salivation rate $\times$ eating time & 58.9 & 50.8 & 48.5 & 68.7 & 5.8 & $\mathrm{~ns}$ & ns & 0.02 \\
\hline Ensalivation $\times$ DMI & 81.8 & 59.7 & 55.5 & 75.9 & 7.9 & $\mathrm{~ns}$ & ns & 0.02 \\
\hline
\end{tabular}

\footnotetext{
${ }^{1} \mathrm{AS}: \mathrm{AH}=$ Ratio of alfalfa silage to alfalfa hay; $\mathrm{CH}=$ chopped hay; $\mathrm{GH}=$ ground hay; and the overall diet was $60 \%$ barley-based concentrate and $40 \%$ forage on a DM basis.

${ }^{2} \mathrm{FPS}=$ forage particle size.

${ }^{3}$ Ratio of total amount of saliva secreted to duration of collection for each individual collection.

${ }^{4}$ Amount of saliva added per gram of feed ingested. $\mathrm{ns}=P>0.15$.
}

mendation. Mertens (2000) recommended that 19.7\% peNDF was needed to maintain a milk fat percentage of $3.4 \%$ for Holstein cows, and $22.3 \%$ peNDF was needed to maintain an average ruminal $\mathrm{pH}$ of 6.0 . However, the proportion of peNDF ${ }_{\mathrm{PS}}$ ranged only from 7.2 to $15 \%$ of the diet DM. Furthermore, it is apparent that peNDF did not influence feed intake. Although pef contents of the diets within the same ratio of AS:AH were different, the DMI were similar.

\section{Chewing Activity, Salivary Secretion, and Particle Size Distribution}

Total eating time (hours per day) was not affected by treatments (Table 5). However, cows spent a longer time eating per unit of feed intake (DM or NDF) when fed low AS:AH than high AS:AH diets. Increasing the proportion of hay in the diet of cows required more time for eating but total eating time was not increased because intake decreased. This effect was not likely due to the FPS, as cows spent similar time eating per unit of feed for diets containing chopped or ground AH. Lack of an effect of the FPS on eating time suggests that even the chopped $\mathrm{AH}$ was below the critical particle size required prior to swallowing.
Cows spent less time ruminating with decreased ratio of AS:AH in the diet or with reduced FPS. Higher ruminating time for the diet with high $\mathrm{AS}: \mathrm{AH}$ ratio compared to the diet with low AS:AH ratio reflected higher DMI rather than a direct effect due to alfalfa preservation because this difference was not evident when ruminating time was expressed per unit of feed intake. In contrast, ruminating time, expressed as minute per unit of intake of DM or NDF, decreased with reduction of the FPS. Similarly, total chewing time was not affected by AS:AH but it was lower for the diet containing ground hay than for the diet containing chopped hay. This finding was in agreement with other reports (Nelson and Satter, 1992; Beauchemin et al., 1997), and indicates that differences between the potential rumination of $\mathrm{AS}$ or $\mathrm{AH}$ are related primarily to particle size rather than method of preservation per se. Beauchemin et al. (1994) reported that the particle size of silage did not affect the eating time but reduced ruminating time.

There were interactions $(P<0.08)$ observed between AS:AH and FPS for ruminating time. Replacing chopped hay with ground hay had a more pronounced effect on ruminating time for low AS:AH than for high AS:AH diets. This effect was likely associated with 
Table 6. Particle size distribution and particle length of diets and digesta of dairy cows fed diets differing in ratio of alfalfa silage to alfalfa hay or forage particle size.

\begin{tabular}{|c|c|c|c|c|c|c|c|c|}
\hline \multirow[b]{3}{*}{ Item } & \multicolumn{4}{|c|}{ Diets $^{1}$} & \multirow[b]{3}{*}{$\mathrm{SE}$} & \multicolumn{3}{|c|}{ Effect $^{2}, P<$} \\
\hline & \multicolumn{2}{|c|}{ AS:AH 50:50 } & \multicolumn{2}{|c|}{ AS:AH 25:75 } & & \multirow[b]{2}{*}{ AS:AH } & \multirow[b]{2}{*}{ FPS } & \multirow{2}{*}{$\begin{array}{l}\text { AS:AH } \\
\times \text { FPS }\end{array}$} \\
\hline & $\mathrm{CH}$ & $\mathrm{GH}$ & $\mathrm{CH}$ & GH & & & & \\
\hline \multicolumn{9}{|l|}{$\mathrm{MPL}^{3}, \mathrm{~mm}$} \\
\hline Diets & 9.78 & 5.13 & 7.45 & 4.42 & 0.56 & 0.06 & 0.01 & $\mathrm{~ns}$ \\
\hline Masticate & 4.33 & 3.69 & 4.47 & 3.55 & 0.43 & ns & 0.12 & $\mathrm{~ns}$ \\
\hline Rumen & 3.65 & 3.29 & 3.44 & 3.19 & 0.16 & $\mathrm{~ns}$ & 0.07 & $\mathrm{~ns}$ \\
\hline Duodenum & 2.88 & 3.05 & 2.77 & 2.22 & 0.41 & $\mathrm{~ns}$ & 0.13 & $\mathrm{~ns}$ \\
\hline \multirow{2}{*}{\multicolumn{9}{|c|}{ DM retained on sieve, $\%$}} \\
\hline \multicolumn{5}{|l|}{ Diets } & & & & \\
\hline $6.70 \mathrm{~mm}$ & 24.8 & 5.5 & 16.3 & 3.2 & 1.9 & 0.05 & 0.01 & $\mathrm{~ns}$ \\
\hline $3.35 \mathrm{~mm}$ & 33.0 & 36.6 & 34.1 & 30.4 & 1.9 & $\mathrm{~ns}$ & $\mathrm{~ns}$ & $\mathrm{~ns}$ \\
\hline $1.18 \mathrm{~mm}$ & 14.2 & 20.9 & 16.7 & 24.3 & 0.9 & 0.04 & 0.01 & ns \\
\hline$<1.18 \mathrm{~mm}$ & 11.1 & 17.8 & 14.2 & 20.4 & 0.5 & 0.02 & 0.01 & $\mathrm{~ns}$ \\
\hline Not retained & 16.9 & 19.2 & 18.7 & 21.7 & 1.1 & 0.14 & 0.08 & $\mathrm{~ns}$ \\
\hline \multicolumn{9}{|l|}{ Masticate } \\
\hline $6.70 \mathrm{~mm}$ & 8.2 & 3.5 & 8.0 & 2.4 & 0.9 & $\mathrm{~ns}$ & 0.01 & $\mathrm{~ns}$ \\
\hline $3.35 \mathrm{~mm}$ & 21.7 & 27.0 & 25.8 & 25.6 & 2.7 & $\mathrm{~ns}$ & 0.1 & 0.07 \\
\hline 1.18 & 21.1 & 21.8 & 21.5 & 21.8 & 1.4 & $\mathrm{~ns}$ & $\mathrm{~ns}$ & $\mathrm{~ns}$ \\
\hline$<1.18 \mathrm{~mm}$ & 14.6 & 16.0 & 15.5 & 18.0 & 0.7 & 0.03 & 0.01 & $\mathrm{~ns}$ \\
\hline Not retained & 34.4 & 31.7 & 29.2 & 32.2 & 4.0 & ns & $\mathrm{ns}$ & $\mathrm{ns}$ \\
\hline \multicolumn{9}{|l|}{ Rumen } \\
\hline $6.70 \mathrm{~mm}$ & 4.6 & 1.0 & 4.6 & 0.8 & 0.6 & $\mathrm{~ns}$ & 0.01 & $\mathrm{~ns}$ \\
\hline $3.35 \mathrm{~mm}$ & 13.6 & 11.7 & 12.9 & 12.0 & 1.6 & $\mathrm{~ns}$ & $\mathrm{~ns}$ & ns \\
\hline $1.18 \mathrm{~mm}$ & 29.8 & 34.8 & 28.5 & 32.6 & 2.0 & 0.07 & 0.01 & $\mathrm{~ns}$ \\
\hline$<1.18 \mathrm{~mm}$ & 29.2 & 26.7 & 28.6 & 26.3 & 2.1 & $\mathrm{~ns}$ & $\mathrm{~ns}$ & $\mathrm{~ns}$ \\
\hline Not retained & 22.8 & 25.8 & 25.4 & 28.3 & 1.5 & 0.09 & 0.05 & $\mathrm{~ns}$ \\
\hline \multicolumn{9}{|l|}{ Duodenum } \\
\hline $3.35 \mathrm{~mm}$ & 4.2 & 3.6 & 3.4 & 2.6 & 0.3 & 0.01 & 0.01 & $\mathrm{~ns}$ \\
\hline $1.18 \mathrm{~mm}$ & 41.8 & 42.7 & 40.0 & 31.9 & 2.5 & 0.02 & $\mathrm{~ns}$ & 0.09 \\
\hline$<1.18 \mathrm{~mm}$ & 18.5 & 20.1 & 17.1 & 19.0 & 1.4 & 0.07 & 0.02 & $\mathrm{~ns}$ \\
\hline Not retained & 35.5 & 33.6 & 39.5 & 46.5 & 3.3 & 0.01 & $\mathrm{~ns}$ & 0.12 \\
\hline
\end{tabular}

${ }^{1} \mathrm{AS}: \mathrm{AH}=$ Ratio of alfalfa silage to alfalfa hay; $\mathrm{CH}=$ chopped hay; $\mathrm{GH}=$ ground hay; and the overall diet was $60 \%$ barley-based concentrate and $40 \%$ forage on a DM basis.

${ }^{2} \mathrm{FPS}=$ forage particle size.

${ }^{3}$ Fifty percent of the particles are greater or less than this length. $\mathrm{ns}=P>0.15$.

intake (kilogram per day) of peNDF rather than the MPL of the diet (Table 6) because the decreased intake of peNDF ${ }_{P S}$ due to replacing chopped hay with ground hay was more pronounced for low AS:AH (42\%) than for high AS:AH (25\%) diets. In contrast, the reduction of diet MPL was less for low (41\%) than for high (48\%) AS:AH diets.

Total chewing time varied from 9.9 to $12.1 \mathrm{~h}$ with ruminating time varying from 4.7 to $7.3 \mathrm{~h}$, which are in the ranges reported previously for dairy cows fed diets containing barley grain and alfalfa (Beauchemin et al., 1994; Yang et al., 2000). High producing dairy cows consuming large quantities of DM tended to ruminate more than $6 \mathrm{~h}$ daily, unless a digestive upset occurs (Beauchemin et al., 1994). This is equivalent to a minimum of $16 \mathrm{~min} / \mathrm{kg}$ of DM for $22 \mathrm{~kg} / \mathrm{d}$ of DMI. In the present study, the shortest rumination time was only $4.6 \mathrm{~h} / \mathrm{d}$ or $13.5 \mathrm{~min} / \mathrm{kg}$ of DMI for cows fed the diet containing low AS:AH and ground hay with the lowest intake of peNDF among the four diets studied. Sudweeks et al. (1981) proposed chewing corrected for DMI as a criterion for physical effectiveness of forages. They further proposed values equal or more than $30 \mathrm{~min} / \mathrm{kg}$ of DMI as suitable for limiting the risk of digestive disorders. In the present study, cows fed the diets containing ground hay either with high or with low AS:AH chewed less $30 \mathrm{~min} / \mathrm{kg}$ of DMI when intake of peNDF ${ }_{\mathrm{M}}$ was below $20 \%$ but cows chewed more than $30 \mathrm{~min} / \mathrm{kg}$ of DMI when the intake of peNDF $_{M}$ was over $23 \%$, indicating that the peNDF, expressed as percentage of DMI, might be a reliable indicator of chewing activity. However, the values of peNDF (\% of DMI) can be much lower when the PSPS technique is applied compared with the $\operatorname{pNDF}_{\mathrm{M}}$ or $\operatorname{peNDF}_{P}>1.18$. Guidelines for dietary levels of peNDF based on chewing time need to be developed.

The rate of saliva secretion during eating was not affected by the treatments and was in the range re- 
ported by Beauchemin (2000) for dairy cows (Table 5 ). This observation supports the previous work that indicates that salivary secretion per minute of mastication is relatively constant, and is not usually affected by diet (Cassida and Stokes, 1986). Similarly, ensalivation of feed, expressed as gram of saliva added per gram of feed swallowed, and as well as total salivary output during the eating period were not affected by the treatments regardless the methods used for estimating salivary output. However, total salivary production during eating was consistently higher when DMI rather than eating time was used in the calculation. This discrepancy indicates that eating time (hours per day) might not be properly estimated by visual observation because DMI and salivation rate were directly measured. Furthermore, there were interactions observed between AS:AH and FPS for salivation rates, ensalivation of feed and saliva production during the eating period. Decreasing peNDF level of the diet by replacing chopped $\mathrm{AH}$ with ground $\mathrm{AH}$ increased saliva secretion in low AS:AH diets but not with high AS:AH diets. It is possible that the addition of ground hay compared with chopped hay increased saliva production more in low silage diets because the ground hay has more potential to absorb free moisture. The quality of the bolus in terms of lubrication and ease of swallowing may be more a function of free moisture than total moisture content. Thus, a smaller amount of saliva is able to lubricate a coarse forage than a fine forage.

Mean particle length and particle size distributions of the diets, masticates and digestive contents are presented in Table 6 . The FPS tended to affect MPL of the diet, the masticate $(P<0.12)$, rumen contents $(P$ $<0.07)$ and duodenal digesta $(P<0.13)$. Although lowering the ratio of AS:AH tended to reduce $(P<0.06)$ the MPL of the diets because the MPL was greater for AS than for AH, it had no effect on MPL of masticate, rumen contents, or duodenal digesta. Furthermore, despite the fact that the MPL declined linearly from the diet to the duodenal digesta for all diets, the reduction of the MPL was greater from diet to masticate than from the masticate to rumen contents or from rumen contents to duodenal digesta, especially for the diets containing chopped hay. In fact, comparing particle distributions between diet and masticate indicates that eating reduced substantially the proportion of particles retained on the 6.7 or $3.35-\mathrm{mm}$ screens with minimal changes in proportions of particles retained or passing through a $1.18-\mathrm{mm}$ screen. The sum of the proportion of the particles retained on the 6.7, 3.35 and $1.18-\mathrm{mm}$ screens varied from 58 to $72 \%$ of the total DM among the diets studied but that of the masticate was relatively consistent and varied from 50 to
$55 \%$. These data indicate that eating activity was more efficient for long particles than for short ones. This finding is in agreement with that of Bailey et al. (1989) who reported that larger feed particles were reduced more in size than smaller ones during eating.

As observed for the MPL, AS:AH had almost no affect on particle distributions of the masticate while the proportion of the particles retained on a $6.7-\mathrm{mm}$ screen was higher for the diet containing chopped hay than for the diet containing ground hay. Consequently, more rumination was needed for the diet containing chopped hay (Table 5).

Influences of the treatments on particle size distributions of rumen contents were quantitatively negligible despite some differences that were statistically significant (Table 6). In the duodenum, no particles were retained on a $6.7-\mathrm{mm}$ screen and the proportion of the particles retained on a $3.35-\mathrm{mm}$ screen was reduced, on average, from $15 \%$ in the rumen contents to $3.5 \%$ in the duodenal digesta while proportion of particles retained on the $1.18-\mathrm{mm}$ screen was increased up to $43 \%$. These data indicate that particles retained on a 1.18-mm screen may not have a high resistance to passage from the rumen to the duodenum in cattle and suggest that the peNDF should be estimated from particles retained on the 3.35 or $2.36-\mathrm{mm}$ screens rather than the $1.18-\mathrm{mm}$ screen.

\section{Rumen Fermentation}

The pattern of diurnal fluctuation of ruminal $\mathrm{pH}$ was generally similar among the treatments (Figure 1). The highest $\mathrm{pH}$ values were observed just before the 8 -am feeding, while the lowest $\mathrm{pH}$ values were between 2000 and $0200 \mathrm{~h}$. Cows fed the diets with low AS:AH or the diets containing chopped hay had ruminal $\mathrm{pH}$ values consistently higher than the cows fed the diets with high AS:AH or the diets containing ground hay. In addition, the $\mathrm{pH}$ curves were relatively flat for the diets with low AS:AH or the diet containing chopped hay. Consequently, mean ruminal $\mathrm{pH}$ tended to be higher $(P<0.10)$ for low AS:AH than for high AS:AH diets, and lower for the diet containing ground hay than for the diet containing chopped hay (Table 7). These results are in agreement with the recommendation (22.3\% peNDF) of Mertens (1997) when peNDF content of the diet is measured from tabular values (Mertens, 2000) or from the particles retained by a $1.18-\mathrm{mm}$ screen. Furthermore, ruminal $\mathrm{pH}$ was mainly affected by FPS rather than AS:AH. In fact, decreased ratio of AS:AH tended to prolong $(P<0.08)$ the period in which $\mathrm{pH}$ was above 6.2. Feeding chopped hay instead of ground hay improved significantly ruminal $\mathrm{pH}$ status: the period in which ruminal $\mathrm{pH}$ was 


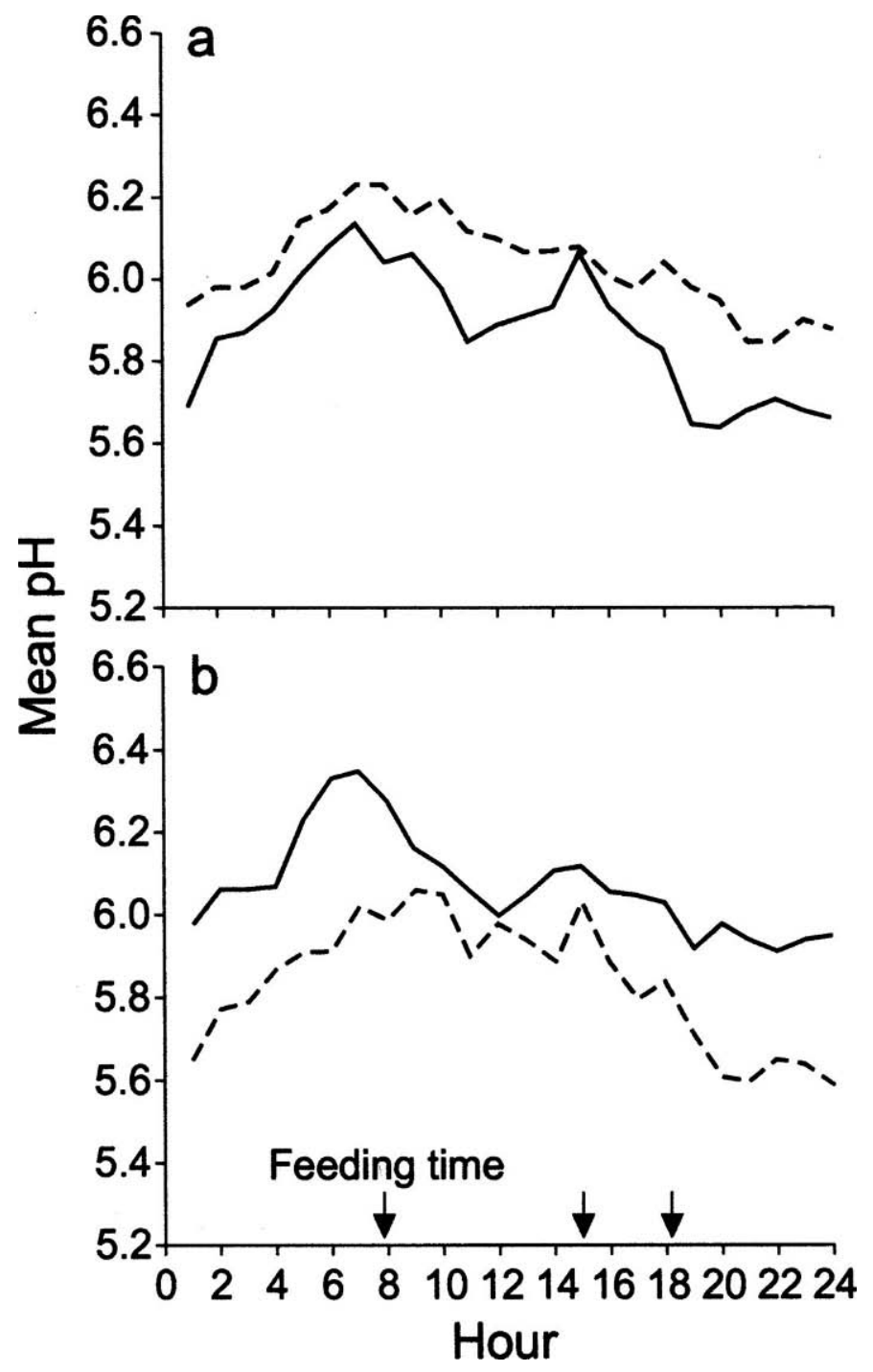

Figure 1. Diurnal fluctuations of rumen $\mathrm{pH}$ affected by ratio of alfalfa silage to alfalfa hay (a; silage:hay, 50:50, —; 25:75, ---) or by particle size of hay (b; chopped, - ; ground, ---). Arrows indicate time of feeding.

above 6.2 tended to increase $(P<0.11)$ and the period during which ruminal $\mathrm{pH}$ was below 5.8 decreased.

Improved ruminal $\mathrm{pH}$ by manipulating the FPS of diets was likely due to increased rumination time. Higher DMI combined with lower eating time (minutes per kilogram of DMI) was probably the major cause for lower ruminal $\mathrm{pH}$ with high $\mathrm{AS}: \mathrm{AH}$ diets. Lower ruminal $\mathrm{pH}$ was consistent with less time spent chewing for diets containing ground hay compared with the diets containing chopped hay. Furthermore, more rapid solubilization of non-cell wall components from the ground hay was possibly an additional factor leading to low ruminal $\mathrm{pH}$.
Effects of AS:AH and FPS on ruminal pH were not consistent with the effects on ruminal VFA content or molar percentage of acetate, propionate or butyrate, which were not affected by the dietary factors studied in the present experiment. The present findings conflict with other results (Nelson and Satter, 1992) in which both the ruminal $\mathrm{pH}$ and VFA concentrations were affected by the particle size of alfalfa. A relatively short sampling period (one day from 1000 to $1600 \mathrm{~h}$ ) for ruminal VFA determination was not as representative as the continuous measurement of ruminal $\mathrm{pH}$ during two days. Ruminal $\mathrm{NH}_{3} \mathrm{~N}$ concentration was similar for diets containing chopped or ground hay but was increased when the AS:AH was reduced. This finding was in contrast to what was expected because AS contained more RDP than did $\mathrm{AH}$.

\section{Production and Composition of Milk}

Milk production tended to be increased by $11.2 \%$ for actual $(P<0.14)$, and $9.8 \%$ for FCM $(P<0.09)$ when AS:AH in the diets of cows was increased from 25:75 to 50:50 (Table 8). However, there were no differences in milk production for cows fed chopped hay or ground hay, reflecting similar trends for DMI. Milk composition was not affected by the AS:AH or FPS. Consequently, milk component yield did not differ for cows fed chopped or ground hay but yield of milk fat tended to be higher $(P<0.07)$ for cows fed high AS:AH than for cows fed low AS:AH diets, because of greater actual milk yield. Trends toward increased milk production by feeding high AS:AH were a result of trends towards increased DMI. Several factors may explain lack of response of milk fat to peNDF content of the diet. Firstly, the NDF contents of the diets in the present study were higher $(36 \%)$ than the minimum (25\%) recommendation of NRC (2001), although the proportion of forage NDF in the diets was the recommended level of 19\%. Beauchemin et al. (1994) and Mertens (1997) concluded that effects of particle size on milk fat content were likely to be observed when NDF levels were below minimum requirements recommended by NRC (1989). Secondly, the lowest peNDF of the $\operatorname{diet}(19.7 \%)$ measured as the particles retained on a 1.18-mm screen, was equal to the recommendation of Mertens (1997) to maintain milk fat at $3.4 \%$ for early to midlactation Holstein cows.

\section{Correlations of peNDF with Chewing Activity or Rumen pH}

Pearson correlation coefficients among the 16 observations for each variable are presented in Table 9. Dietary particle sizes, expressed as MPL, peNDF $_{M}$ or 
Table 7. Characteristics of rumen fermentation of dairy cows fed diets differing in ratio of alfalfa silage to alfalfa hay or forage particle size.

\begin{tabular}{|c|c|c|c|c|c|c|c|c|}
\hline \multirow[b]{3}{*}{ Item } & \multicolumn{4}{|c|}{$\operatorname{Diets}^{1}$} & \multirow[b]{3}{*}{ SE } & \multicolumn{3}{|c|}{ Effect $^{2}, P<$} \\
\hline & \multicolumn{2}{|c|}{ AS:AH 50:50 } & \multicolumn{2}{|c|}{ AS:AH 25:75 } & & \multirow[b]{2}{*}{ AS:AH } & \multirow[b]{2}{*}{ FPS } & \multirow{2}{*}{$\begin{array}{l}\text { AS:AH } \\
\times \text { FPS }\end{array}$} \\
\hline & $\overline{\mathrm{CH}}$ & GH & $\overline{\mathrm{CH}}$ & GH & & & & \\
\hline \multicolumn{9}{|l|}{$\mathrm{pH}$} \\
\hline Mean & 5.97 & 5.78 & 6.18 & 5.90 & 0.15 & 0.10 & 0.02 & $\mathrm{~ns}$ \\
\hline Area $\mathrm{pH}<5.8, \mathrm{pH}^{*} \mathrm{~h}$ & 2.1 & 3.7 & 0.9 & 4.5 & 1.1 & $\mathrm{~ns}$ & 0.01 & $\mathrm{~ns}$ \\
\hline Area $\mathrm{pH}<6.2, \mathrm{pH}^{*} \mathrm{~h}$ & 6.9 & 10.5 & 4.4 & 10.2 & 2.2 & $\mathrm{~ns}$ & 0.01 & $\mathrm{~ns}$ \\
\hline$>6.20, \mathrm{~h}$ & 7.3 & 3.5 & 11.0 & 7.6 & 3.3 & 0.08 & 0.11 & $\mathrm{~ns}$ \\
\hline$<5.80, \mathrm{~h}$ & 7.5 & 13.0 & 5.1 & 11.7 & 2.6 & $\mathrm{~ns}$ & 0.01 & $\mathrm{~ns}$ \\
\hline Lowest & 5.40 & 5.26 & 5.66 & 5.42 & 0.14 & 0.07 & 0.09 & $\mathrm{~ns}$ \\
\hline \multicolumn{9}{|l|}{ VFA } \\
\hline $\begin{array}{l}\text { Total, } \mathrm{m} M \\
\mathrm{~mol} / 100 \mathrm{~mol}\end{array}$ & 143.4 & 145.7 & 133.3 & 133.7 & 10.8 & $\mathrm{~ns}$ & $\mathrm{~ns}$ & $\mathrm{~ns}$ \\
\hline Acetate (A) & 64.4 & 65.6 & 67.9 & 66.0 & 1.5 & $\mathrm{~ns}$ & $\mathrm{~ns}$ & $\mathrm{~ns}$ \\
\hline Propionate (P) & 20.1 & 18.1 & 17.5 & 18.8 & 2.0 & $\mathrm{~ns}$ & $\mathrm{~ns}$ & $\mathrm{~ns}$ \\
\hline Butyrate & 11.7 & 11.7 & 10.6 & 11.3 & 0.8 & $\mathrm{~ns}$ & $\mathrm{~ns}$ & $\mathrm{~ns}$ \\
\hline $\mathrm{A}: \mathrm{P}$ & 3.41 & 3.72 & 3.95 & 3.77 & 0.45 & $\mathrm{~ns}$ & $\mathrm{~ns}$ & $\mathrm{~ns}$ \\
\hline $\mathrm{NH}_{3} \mathrm{~N}, \mathrm{~m} M$ & 3.23 & 3.55 & 4.80 & 4.05 & 0.48 & 0.01 & $\mathrm{~ns}$ & 0.13 \\
\hline
\end{tabular}

${ }^{1} \mathrm{AS}: \mathrm{AH}=$ Ratio of alfalfa silage to alfalfa hay; $\mathrm{CH}=$ chopped hay; $\mathrm{GH}=$ ground hay; and the overall diet was $60 \%$ barley-based concentrate and $40 \%$ forage on a DM basis.

${ }^{2} \mathrm{FPS}=$ forage particle size.

$\mathrm{ns}=P>0.15$.

peNDF $F_{P>1.18}$ were moderately correlated with ruminating or total chewing time $(\mathrm{r} \geq 0.52, P<0.05)$ but not with eating time, and the peNDF $\mathrm{PS}_{\text {S }}$ only tended to correlate to ruminating time $(\mathrm{r}=0.44, P<0.10)$. Lack of correlation between peNDF and eating time indicated that no effect of peNDF on eating time was observed. Low correlation of intake of peNDF $\mathrm{PS}_{\mathrm{PS}}$ with chewing activity was not expected because the
peNDF ${ }_{\mathrm{PS}}$ represents the portion of the coarse particles of the diets which supposedly stimulate chewing activity. However, there were considerable differences in the proportion of coarse particles of the diets measured using the PSPS or the wet sieving technique. The proportion of particles retained on the $8 \mathrm{~mm}$ sieve of the PSPS was $31.5,30.7,37.7$, and $21.8 \%$ while that retained on the $6.7 \mathrm{~mm}$ screen used in wet sieving was

Table 8. Milk production and composition of dairy cows fed diets differing in ratio of alfalfa silage to alfalfa hay or forage particle size.

\begin{tabular}{|c|c|c|c|c|c|c|c|c|}
\hline \multirow[b]{3}{*}{ Item } & \multicolumn{4}{|c|}{$\operatorname{Diets}^{1}$} & \multirow[b]{3}{*}{$\mathrm{SE}$} & \multicolumn{3}{|c|}{ Effect $^{2}, P<$} \\
\hline & \multicolumn{2}{|c|}{ AS:AH 50:50 } & \multicolumn{2}{|c|}{ AS:AH 25:75 } & & \multirow[b]{2}{*}{ AS:AH } & \multirow[b]{2}{*}{ FPS } & \multirow{2}{*}{$\begin{array}{l}\text { AS:AH } \\
\times \text { FPS }\end{array}$} \\
\hline & $\mathrm{CH}$ & $\mathrm{GH}$ & $\mathrm{CH}$ & GH & & & & \\
\hline \multicolumn{9}{|l|}{ Milk yield, kg/d } \\
\hline Actual & 29.4 & 29.2 & 26.2 & 26.5 & 2.9 & 0.14 & $\mathrm{~ns}$ & $\mathrm{~ns}$ \\
\hline $4 \% \mathrm{FCM}$ & 28.3 & 27.9 & 25.3 & 25.9 & 2.1 & 0.09 & $\mathrm{~ns}$ & $\mathrm{~ns}$ \\
\hline \multicolumn{9}{|l|}{ Milk fat } \\
\hline$\%$ & 3.92 & 3.78 & 3.80 & 3.93 & 0.44 & $\mathrm{~ns}$ & $\mathrm{~ns}$ & $\mathrm{~ns}$ \\
\hline $\mathrm{kg} / \mathrm{d}$ & 1.10 & 1.08 & 0.98 & 1.02 & 0.09 & 0.07 & $\mathrm{~ns}$ & $\mathrm{~ns}$ \\
\hline \multicolumn{9}{|l|}{ Milk protein } \\
\hline$\%$ & 3.26 & 3.34 & 3.31 & 3.31 & 0.16 & $\mathrm{~ns}$ & $\mathrm{~ns}$ & $\mathrm{~ns}$ \\
\hline $\mathrm{kg} / \mathrm{d}$ & 0.95 & 0.96 & 0.87 & 0.87 & 0.10 & $\mathrm{~ns}$ & $\mathrm{~ns}$ & $\mathrm{~ns}$ \\
\hline \multicolumn{9}{|l|}{ Milk lactose } \\
\hline$\%$ & 4.62 & 4.63 & 4.57 & 4.60 & 0.07 & $\mathrm{~ns}$ & $\mathrm{~ns}$ & $\mathrm{~ns}$ \\
\hline $\mathrm{kg} / \mathrm{d}$ & 1.36 & 1.35 & 1.20 & 1.22 & 0.13 & $\mathrm{~ns}$ & $\mathrm{~ns}$ & $\mathrm{~ns}$ \\
\hline $4 \% \mathrm{FCM} / \mathrm{DMI}$ & 1.22 & 1.19 & 1.27 & 1.27 & 0.10 & $\mathrm{~ns}$ & $\mathrm{~ns}$ & $\mathrm{~ns}$ \\
\hline
\end{tabular}

${ }^{1} \mathrm{AS}: \mathrm{AH}$ = Ratio of alfalfa silage to alfalfa hay; $\mathrm{CH}=$ chopped hay; $\mathrm{GH}$ = ground hay; and the overall diet was $60 \%$ barley-based concentrate and $40 \%$ forage on a DM basis.

${ }^{2} \mathrm{FPS}=$ forage particle size.

$\mathrm{ns}=P>0.15$. 


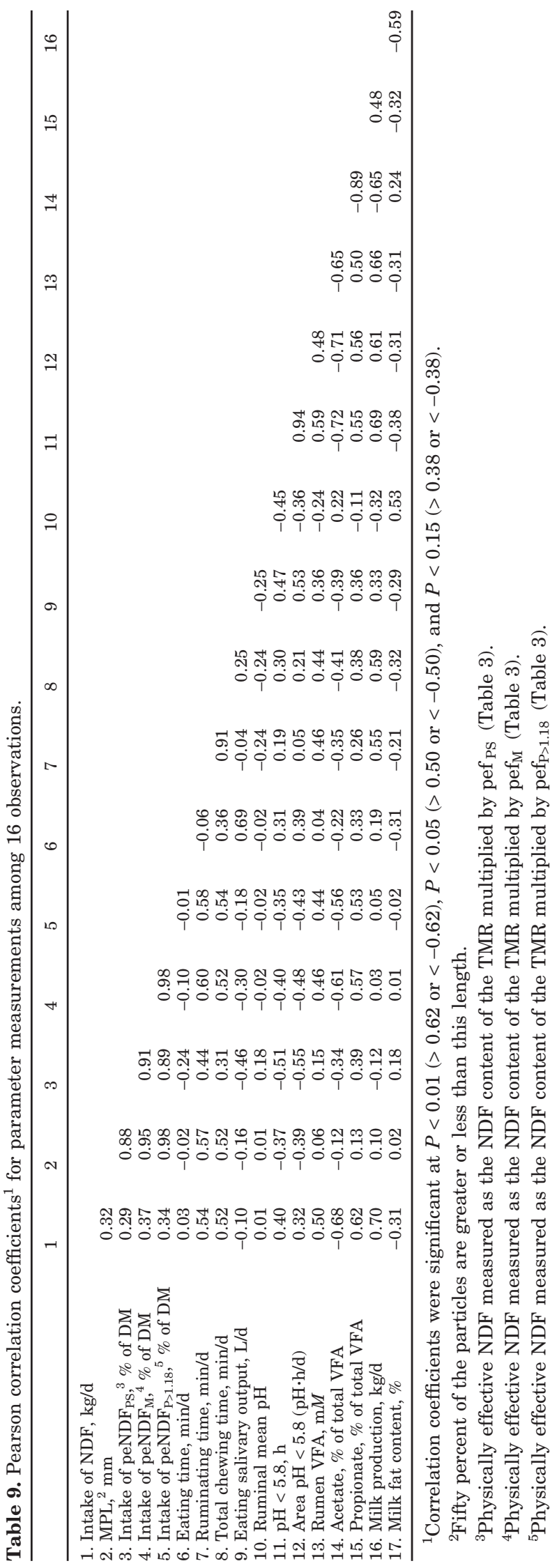

$24.8,5.5,16.3,3.2 \%$ for the four diets studied, respectively. Apparently, compared with wet sieving, the PSPS overestimated the proportion of coarse particles, especially for the diets containing a high proportion of fine particles.

The MPL or peNDF of the diets were not correlated to mean ruminal $\mathrm{pH}$ but were negatively correlated to the area below pH 5.8 and the time during which ruminal $\mathrm{pH}$ was below 5.8. Reducing this area indicated an increase of ruminal $\mathrm{pH}$ and a reduction of ruminal $\mathrm{pH}$ fluctuations. The negative correlation between peNDF of the diets and the area below pH 5.8 was likely related to rumination time rather than eating time. Rumen $\mathrm{pH}$ below 5.8 mostly occurred during night-time rather than during day-time (Figure 1). Hence, increasing ruminating time rather than increasing eating time may be a more efficient means of improving ruminal $\mathrm{pH}$ status. Increased ruminating time could be achieved by manipulating the peNDF content of diet as it was positively correlated to ruminating time. These results suggest that increased peNDF content of the diet may not affect mean ruminal $\mathrm{pH}$ but may reduce the risk of acidosis by decreasing the time and area that $\mathrm{pH}$ is below 5.8. A positive correlation between ruminal $\mathrm{pH}$ and milk fat content ( $\mathrm{r}=0.53, P<0.05$ ) was expected as high ruminal $\mathrm{pH}$ promotes fiber digestion which produces precursors for milk and milk fat synthesis.

\section{CONCLUSIONS}

Estimates of physically effective NDF content of diets differed for the various techniques used. The physically effective NDF content of the diets was much lower when measured using the Penn State Particle Separator than when measured based on particles retained on a 1.18-mm screen or from tabular values of chewing times. Increasing physically effective NDF content of dairy cow diets increased chewing activity, especially ruminating time, and improved rumen $\mathrm{pH}$ status. The peNDF was a reliable indication of chewing activity and subclinical ruminal acidosis (time and area below $\mathrm{pH}$ 5.8), but not mean ruminal $\mathrm{pH}$. Furthermore, chewing activity was related more to peNDF $_{M}$ and peNDF $F_{P>1.18}$ than peNDF ${ }_{P S}$. About $22 \%$ of DMI as peNDF is needed in dairy cow diets to maintain an average ruminal $\mathrm{pH}$ of 6.0 when using particles retained on a 1.18-mm screen to determine the peNDF level. Further study is warranted to validate these different systems for optimizing level of the peNDF in the dairy cow diet.

\section{ACKNOWLEDGMENTS}

This experiment was financially supported by the Alberta Dairy Producers (Edmonton, AB), the Canada/ 
Alberta Livestock Research Trust (Lethbridge, AB), and the Matching Investment Initiative of Agriculture and Agri-Food Canada. The authors thank B. Farr, J. Erickson, C. Holmes, K. Andrews, S. Eivemark, G. Bowman, L. Madge, J. Chang, D. Vedres, and A. Zook for their assistance in performing laboratory analyses and the staff of the Lethbridge Research Centre Dairy Unit for care of the cows and milk sample collection.

\section{REFERENCES}

Association of Official Analytical Chemists. 1990. Official Methods of Analysis. Vol. I. 15th ed. AOAC, Arlington, VA.

Bailey, A. T., R. A. Erdman, L. W. Smith, and B. K. Sharma. 1989 Particle size reduction during initial mastication of forages by dairy cattle. J. Anim. Sci. 68:2084-2094.

Beauchemin, K. A. 2000. Managing rumen fermentation in barleybased diets: Balance between high production and acidosis. Advance in Dairy Technology, 12:109-125.

Beauchemin, K. A., and J. G. Buchanan-Smith. 1989. Effects of dietary neutral detergent fiber concentration and supplementary long hay on chewing activities and milk production of dairy cows. J. Dairy Sci. 72:2288-2300.

Beauchemin, K. A., B. I. Farr, L. M. Rode, and G. B. Schaalje. 1994. Effects of alfalfa silage chop length and supplementary long hay on chewing and milk production of dairy cows. J. Dairy Sci. 77:1326-1339.

Beauchemin, K. A., L. M. Rode, and M. V. Eliason. 1997. Chewing activities and milk production of dairy cows fed alfalfa as hay, silage, or dried cubes of hay or silage. J. Dairy Sci. 80:324-333.

Belyea, R. L., P. J. Martin, and H. T. Sedgwick. 1985. Utilization of chopped and long alfalfa for dairy cows. J. Dairy Sci. 68:1297-1301.

Broderick, G. A. 1995. Performance of lactating dairy cows fed either alfalfa silage or alfalfa hay as the sole forage. J. Dairy Sci. 78:320-329

Cassida, K. A., and M. R. Stokes. 1986. Eating and resting salivation in early lactation dairy cows. J. Dairy Sci. 69:1282-1292.

Jaster, E. H., and M. R. Murphy. 1983. Effects of varying particle size of forage on digestion and chewing behavior of dairy heifers. J. Dairy Sci. 66:802-810.

Lammers, B. P., D. R. Buckmaster, and A. J. Heinrichs. 1996. A simple method for the analysis of particle sizes of forage and total mixed rations. J. Dairy Sci. 79:922-928.

Mertens, D. R. 1997. Creating a system for meeting the fiber requirements of dairy cows. J. Dairy Sci. 80:1463-1481.

Mertens, D. R. 2000. Physically effective NDF and its use in dairy rations explored. Feedstuffs. Pages 11-14, April 10, 2000.

National Research Council. 1989. Nutrient Requirements of Dairy Cattle. 6th rev. ed. Natl. Acad. Sci., Washington, DC.
National Research Council. 2001. Nutrient Requirements of Dairy Cattle. 7th rev. ed. Natl. Acad. Sci., Washington, DC.

Nelson, W. F., and L. D. Satter. 1990. Effect of stage of maturity and method of preservation of alfalfa on production by lactating dairy cows. J. Dairy Sci. 73:1800-1811.

Nelson, W. F., and L. D. Satter. 1992. Impact of alfalfa maturity and preservation method on milk production by cows in early lactation. J. Dairy Sci. 75:1562-1570.

Rode, L. M., and L. D. Satter. 1988. Effect of amount and length of alfalfa hay in diets containing barley or corn on site of digestion and rumen microbial protein synthesis in dairy cows. Can. J. Anim. Sci. 68:445-454

Rode, L. M., D. C. Weakley, and L. D. Satter. 1985. Effect of forage amount and particle size in diets of lactating dairy cows on site of digestion and microbial protein synthesis. Can. J. Anim. Sci. 65:101-111.

Rode, L. M., W. Z. Yang, and K. A. Beauchemin. 1999. Fibrolytic enzyme supplements for dairy cows in early lactation. J. Dairy Sci. 82:2121-2126.

Russell, J. B. and D. B. Wilson. 1996. Why are ruminal cellulolytic bacteria unable to digest cellulose at low $\mathrm{pH}$ ? J. Dairy Sci. 79:1503-1509.

Santini, F. J., A. R. Hardie, N. A. Jorgensen, and M. F. Finner. 1983. Proposed use of adjusted intake based on forage particle length for calculation of roughage indexes. J. Dairy Sci. $66: 811-820$

SAS User's Guide: Statistics, Version 6 Edition. 1996. SAS Inst., Inc., Cary, NC.

Soita, H. W., D. A. Christensen, and J. J. McKinnon. 2000. Influence of particle size on the effectiveness of the fiber in barley silage. J. Dairy Sci. 83:2295-2300.

Sudweeks, E. M., L. O. Ely, D. R. Mertens, and L. R. Sisk. 1981. Assessing minimum amounts and form of roughages in ruminant diets:roughage value index system. J. Anim. Sci. $53: 1406-1411$.

Vaage, A. S., and J. A. Shelford. 1984. Weibull-type function to describe particle length in chopped forage. Page 177 in Techniques in Particle Size Analysis of Feed and Digesta in Ruminants. P. M. Kennedy, ed. Can. Soc. Anim. Sci. Occas. Publ. No. 1.

Vaage, A. S., J. A. Shelford, and G. Moseley. 1984. Theoretical basis for the measurement of particle length when sieving elongated feed particles. Pages 76-82 in Techniques in Particle Size Analysis of Feed and Digesta in Ruminants. P. M. Kennedy, ed. Can. Soc. Anim. Sci. Occas. Publ. No. 1.

Van Soest, P. J., J. B. Robertson, and B. A. Lewis. 1991. Methods for dietary fiber, neutral detergent fiber and non-starch polysaccharide in relation to animal nutrition. J. Dairy Sci. 74:35833597.

Weatherburn, M. W. 1967. Phenol-hypochlorite reaction for determination of ammonia. Anal. Chem. 39:971-974.

Yang, W. Z., K. A. Beauchemin, and L. M. Rode. 2000. Effects of barley grain processing on extent of digestion and milk production of lactating cows. J. Dairy Sci. 83:554-568. 